Article

\title{
The Influence of Water and Nitrogen Availability on the Expression of End-Use Quality Parameters of Spring Wheat
}

\author{
Rui Yang ${ }^{1}$, Xi Liang ${ }^{1, *(\mathbb{D})}$, Jessica A. Torrion ${ }^{2}$, Olga S. Walsh ${ }^{3}{ }^{\mathbb{C}}$, Katherine $\mathrm{O}^{\prime}$ Brien $^{4}$ \\ and Qian Liu ${ }^{5}$ \\ 1 Department of Plant Sciences, Aberdeen Research and Extension Center, University of Idaho, \\ Aberdeen, ID 83210, USA; ruiy@uidaho.edu \\ 2 Northwestern Agricultural Research Center, Montana State University, Kalispell, MT 59901, USA; \\ jessica.torrion@montana.edu \\ 3 Department of Plant Sciences, Parma Research and Extension Center, University of Idaho, \\ Parma, ID 83660, USA; owalsh@uidaho.edu \\ 4 Wheat Quality Lab, Aberdeen Research and Extension Center, University of Idaho, \\ Aberdeen, ID 83210, USA; katho@uidaho.edu \\ 5 College of Food Science, Northeast Agricultural University, Harbin 150030, China; liuqian@neau.edu.cn \\ * Correspondence: xliang@uidaho.edu; Tel.: +1-208-397-4181
}

Received: 24 September 2018; Accepted: 4 November 2018; Published: 10 November 2018

check for updates

\begin{abstract}
Wheat (Triticum aestivum L.) grain quality is determined by multiple physical and chemical attributes. However, previous studies mainly focused on protein quantity and composition, which may not be adequate for understanding grain quality, especially end-use quality. Field experiments were conducted at two locations for two years to better understand how and to what extent water and nitrogen $(\mathrm{N})$ availability affect flour end-use quality. Four drought stress levels (i.e., mild, moderate, severe, and well-watered) and four $\mathrm{N}$ rates (i.e., zero, low, medium, and high) were applied to two spring wheat cultivars (i.e., Dayn and Egan). Evaluated end-use quality traits, including milling quality, mixograph parameters, flour protein and gluten contents, solvent retention capacity (SRC), and baking quality. Most end-use quality parameters were not significantly different between the well-watered treatment and mild drought stress in both cultivars. Nitrogen availability above the low rate $\left(168 \mathrm{~kg} \mathrm{~N} \mathrm{ha}^{-1}\right)$ failed to further improve most end-use quality traits in either cultivar. Among all the end-use quality traits, lactic acid SRC may be a reliable indicator of flour end-use quality. These results indicate that mild drought stress (i.e., a 25\% reduction in irrigation throughout the growing season) may not negatively affect end-use quality and excessive $\mathrm{N}$ fertilization offers minimal improvement in end-use quality. Such information could facilitate the development of irrigation and fertilization guidelines targeting at grain quality.
\end{abstract}

Keywords: baking quality; drought stress; $\mathrm{N}$ rate; gluten; protein; solvent retention capacity

\section{Introduction}

Wheat (Triticum aestivum L.) is one of the most important food crops worldwide [1]. Due to the distinctive viscoelastic properties of the dough, wheat has been utilized for various food products such as bread, cookies, cakes, and noodles, consisting of approximately $20 \%$ of calories and proteins in the human diet [2,3]. Thus, both optimum grain yield and consistent quality should be achieved to meet the food demand.

Wheat grain quality is mainly determined by endosperm texture (i.e., grain hardness), protein content, and gluten strength [4], which are affected by genetics and environment, as well as their 
interaction [5-11]. For instance, grain protein content and gluten strength are related to loci for high molecular weight glutenin subunits (e.g., Glu-A1, Glu-B1, Glu-D1) and the introgression of high grain protein genes (e.g., Gpc-B1) [12-14]. Among the many environmental factors affecting wheat quality, the availability of water and nitrogen $(\mathrm{N})$ is often the most influential [15-19]. It has been widely reported that grain protein content increases under drought stress [15,20-22]; however, responses of gluten-related parameters to reduced water availability are not consistent among previous studies. For instance, Saint Pierre et al. [19] and Guttieri et al. [15] reported that reduced irrigation did not affect mixograph parameters (e.g., mixograph peak height, an indicator of gluten strength) among various wheat genotypes, whereas Ozturk and Aydin [23] observed increased gluten strength and wet gluten content in response to late season drought stress compared to the full irrigation treatment. Inconsistent results may be partially attributable to varied intensity and duration of drought stress and different cultivars/genotypes adopted in previous studies.

Grain protein content generally increases with $\mathrm{N}$ fertilization, resulting in increased gliadins and glutenins, the two major components of gluten [15-19]. However, agreement on responses of gluten properties to $\mathrm{N}$ availability has not been achieved from previous studies. For instance, Saint Pierre et al. [19] observed decreased mixograph peak time in response to increased $\mathrm{N}$ fertilization, while Guttieri et al. [15] reported the opposite results. The lack of consistency may result from genetic diversity (e.g., variation in protein composition) as well as environmental heterogeneity [16-19,24].

Wheat grain quality is determined by a combination of physical and chemical parameters. Many of the previous studies focused on protein quantity and composition [16,17], which may not be adequate for understanding grain quality, especially the end-use quality. Other grain quality attributes, such as milling quality and gluten strength, need to be evaluated for their suitability as reliable grain quality indicators. In addition, there is still limited knowledge on how and to what extent water and $\mathrm{N}$ availability affect wheat quality attributes other than grain protein, particularly milling quality, mixograph parameters, and bread-baking quality, in various environments. Such knowledge will greatly facilitate water and $\mathrm{N}$ management in wheat production to achieve optimal end-use quality, as most irrigation and fertilization guidelines are targeted at grain yield rather than grain quality. For better understanding of the effects of water and $\mathrm{N}$ availability on grain quality (e.g., milling quality, protein, mixograph parameters, and baking quality), we examined two spring wheat cultivars in response to different drought stress levels and $\mathrm{N}$ application rates and analyzed the relationships between grain quality parameters in two environments in the Northwestern U.S.

\section{Materials and Methods}

\subsection{Site Description}

Field experiments were performed in 2016 and 2017 at the University of Idaho Aberdeen Research and Extension Center (AREC; $42.96^{\circ} \mathrm{N}, 112.93^{\circ} \mathrm{W}$; elevation $1342 \mathrm{~m}$ ), Aberdeen, ID, and at the Montana State University Northwestern Agricultural Research Center (NWARC; $48.19^{\circ} \mathrm{N}, 114.13^{\circ} \mathrm{W}$; elevation $901 \mathrm{~m}$ ), Kalispell, MT. Soil types were Declo loam (coarse-loamy, mixed, superactive, mesic Xeric Haplocalcids) at the AREC and Flathead fine sandy loam (coarse-loamy, mixed, superactive, frigid Pachic Haplustolls) at the NWARC. Characteristics of the top $60-\mathrm{cm}$ soils at each site and each year are listed in Table 1. The preceding crop was potato (Solanum tuberosum L.) in the 2016 experiment, and the field for the 2017 experiment was fallowed in the previous year at AREC. At NWARC, alfalfa (Medigo sativa L.) and Barley (Hordeum vulgare) were the preceding crops for experiments in 2016 and 2017, respectively. Soil residual N at each site and each year was rated as "low" to "medium" according to the soil testing reports, which allows additional $\mathrm{N}$ fertilizer application according to University of Idaho [25] and Montana State University [26] fertilizer guidelines for spring wheat. 
Table 1. Characterization of the top 60-cm soil at the Aberdeen Research and Extension Center (AREC), Aberdeen, ID, and the Northwest Agricultural Research Center (NWARC), Kalispell, MT, in 2016 and 2017.

\begin{tabular}{|c|c|c|c|c|c|c|c|c|}
\hline \multirow[b]{2}{*}{ Site-Year } & \multirow[b]{2}{*}{$\mathrm{pH}^{1}$} & \multirow[b]{2}{*}{$\mathrm{OM}^{2}$} & \multicolumn{3}{|c|}{ Soil Residual N ${ }^{3}$} & \multirow[b]{2}{*}{$\mathbf{P}^{4}$} & \multirow[b]{2}{*}{$\mathbf{K}$} & \multirow[b]{2}{*}{$\mathrm{SO}_{4}{ }^{2-}-\mathrm{S}$} \\
\hline & & & Inorganic $\mathbf{N}$ & $\begin{array}{l}\text { Mineralized } \\
\mathrm{N} \text { from } \mathrm{OM}\end{array}$ & $\begin{array}{l}\text { Mineralized N from } \\
\text { Preceding Legume }\end{array}$ & & & \\
\hline & & $\%$ & \multicolumn{3}{|c|}{$\mathrm{kg} \mathrm{Nha}^{-1}$} & \multicolumn{3}{|c|}{$\mathrm{mg} \mathrm{kg}^{-1}$} \\
\hline \multicolumn{9}{|l|}{ AREC } \\
\hline 2016 & 8.3 & 1.1 & 119 & 0 & $\mathrm{~N} / \mathrm{A}^{5}$ & 21 & 175 & 20 \\
\hline 2017 & 8.3 & 1.3 & 156 & 0 & $\mathrm{~N} / \mathrm{A}$ & 15 & 175 & 16 \\
\hline \multicolumn{9}{|l|}{ NWARC } \\
\hline 2016 & 7.6 & 2.7 & 36.6 & 11.8 & 39.2 & 10 & 95 & 6 \\
\hline 2017 & 7.8 & 2.5 & 19.5 & 8.4 & $\mathrm{~N} / \mathrm{A}$ & 10 & 112 & 9 \\
\hline
\end{tabular}

\begin{abstract}
${ }^{1}$ Soil $\mathrm{pH}$ was analyzed using 1:1 soil/water ratio $(w / v) .{ }^{2}$ Soil organic matter (OM) was analyzed using the weight-loss-on-ignition method. ${ }^{3}$ Inorganic $\mathrm{N}$ (i.e., $\mathrm{NH}_{4}{ }^{-}$and $\mathrm{NO}_{3}{ }^{-} \mathrm{N}$ ) was extracted using $0.2 \mathrm{M} \mathrm{KCl} \mathrm{solution}$ and analyzed using colorimetric method. Mineralized $\mathrm{N}$ from OM was estimated at a rate of $16.8 \mathrm{~kg} \mathrm{~N} \mathrm{ha}^{-1}$ for each percent of $\mathrm{OM}$ exceeding $2 \%$ [26]. Estimated $\mathrm{N}$ credit from alfalfa as a preceding crop is $39.2 \mathrm{~kg} \mathrm{~N} \mathrm{ha}^{-1}$ [25]. ${ }^{4}$ Soil $\mathrm{P}, \mathrm{K}$, and $\mathrm{SO}_{4}{ }^{2-}-\mathrm{S}$ were extracted using $0.5 \mathrm{M} \mathrm{NaHCO}_{3}, 1 \mathrm{M} \mathrm{NH}_{4} \mathrm{OAc}$, and $0.2 \mathrm{M} \mathrm{KCl}$ solution, respectively, and analyzed using inductively coupled plasma-optical emission spectrometer (ICP-OES). ${ }^{5} \mathrm{~N} / \mathrm{A}$ : no applicable.
\end{abstract}

Experimental plots were $3.0 \times 6.1 \mathrm{~m}$ with 18 - $\mathrm{cm}$ row spacing, and the seeding rate was 2,500,000 seeds ha ${ }^{-1}$ for both locations. A hard white spring wheat (cv. 'Dayn') and a hard red spring wheat (cv. 'Egan') were planted at the AREC and NWARC, respectively. Dates of planting and harvesting were 12 April and 29 July in 2016 and 22 April and 22 August in 2017 at the AREC, and 22 April and 18 August in 2016, and 3 May and 11 August in 2017 at the NWARC. Rainfall during the growing seasons, quantity of irrigation for the well-watered treatment (see below), and minimum and maximum daily air temperature at each site and each year are illustrated in Figure 1. Ten-year (2005-2015) mean rainfall during the growing season of spring wheat (May-August) is 66 and $186 \mathrm{~mm}$ at the AREC and NWARC, respectively. Therefore, rainfall in this study are considered "normal", except for the 2017 season at the NWARC, which is $\sim 60 \%$ lower than the 10-year mean value. 

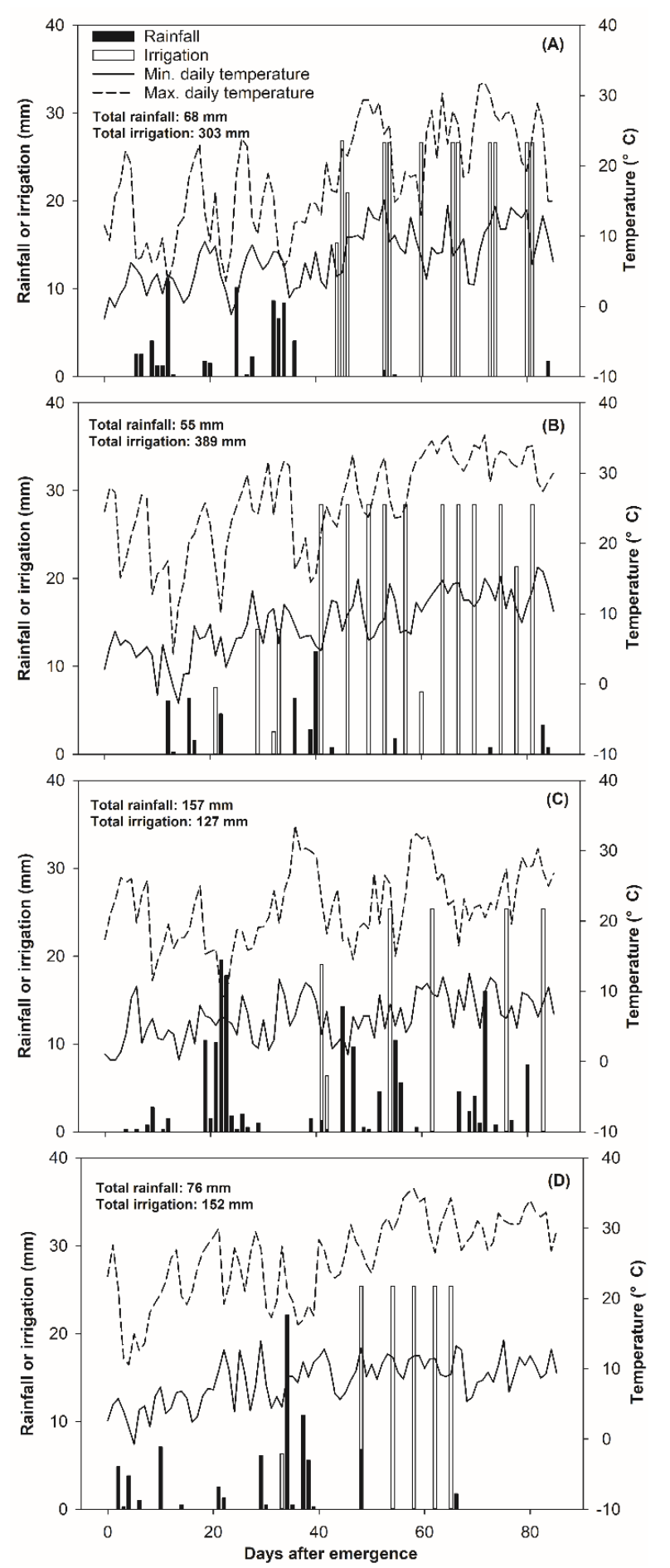

Figure 1. Rainfall, irrigation for the well-watered treatment, and minimum and maximum daily air temperature at the Aberdeen Research and Extension Center, Aberdeen, ID in 2016 (A) and 2017 (B), and at the Northwest Agricultural Research Center, Kalispell, MT in 2016 (C) and 2017 (D).

\subsection{Experimental Design}

At both the AREC and NWARC, the experiment was established following a split-plot design with four replications in each year. The main plot factor was drought stress, including a well-watered treatment, as well as mild, moderate, and severe drought stress levels, which were achieved through irrigation at $100,75,50$, and $0 \%$ of crop evapotranspiration $\left(\mathrm{ET}_{\mathrm{c}}\right)$ replenishment throughout the growing season. Daily $\mathrm{ET}_{\mathrm{c}}$ was calculated by multiplying daily atmospheric grass-referenced 
evapotranspiration $\left(\mathrm{ET}_{\mathrm{o}}\right)$ with crop coefficient $\left(\mathrm{K}_{\mathrm{c}}\right)$. Daily $\mathrm{ET}_{\mathrm{o}}$ was retrieved from the AgriMet Cooperative Agricultural Weather Network weather stations located within $1 \mathrm{~km}$ of each experimental site. The $\mathrm{K}_{\mathrm{c}}$ values for key growth stages of spring wheat were obtained from Allen et al. [27] and daily $\mathrm{K}_{\mathrm{c}}$ was calculated using a linear interpolation method. Irrigation was applied via surface dripping systems when $35 \%$ of the plant available water in the soil was depleted [28]. Irrigation was terminated at Zadoks 77-83 stages (i.e., late milking to soft dough stages) [29]. At AREC, seasonal water intake from rainfall and irrigation in 2016 was 371 (Figure 1A), 295, 220, and $68 \mathrm{~mm}$ for the well-watered treatment, and mild, moderate, and severe drought stresses, respectively; and 444 (Figure 1B), 347, 250, and $55 \mathrm{~mm}$ in 2017. At NWARC, seasonal water intake in 2016 was 284 (Figure 1C), 252, 221, and $157 \mathrm{~mm}$ for the well-watered treatment, and mild, moderate, and severe drought stresses, respectively; and 228 (Figure 1D), 190, 152, and $76 \mathrm{~mm}$ in 2017.

Nitrogen rate was the subplot factor, including zero, low, medium, and high $\mathrm{N}$ rates. The zero $\mathrm{N}$ rate represented soil residual $\mathrm{N}$ (Table 1). The low, medium, and high $\mathrm{N}$ rates targeted 168, 224, and $280 \mathrm{~kg} \mathrm{~N} \mathrm{ha}^{-1}$, from soil residual $\mathrm{N}$ and $\mathrm{N}$ application. The high $\mathrm{N}$ rate was developed based on the guidelines of University of Idaho [25] and Montana State University [26] for crop fertilization under irrigated conditions. To achieve grain yield of $8070 \mathrm{~kg} \mathrm{ha}^{-1}$, total required $\mathrm{N}$ (from soil residual N and $\mathrm{N}$ application) is $269 \mathrm{~kg} \mathrm{~N} \mathrm{ha}^{-1}$ in southern Idaho, and to achieve grain yield of $6725 \mathrm{~kg} \mathrm{ha}^{-1}$, the total required $\mathrm{N}$ is $370 \mathrm{~kg} \mathrm{~N} \mathrm{ha}^{-1}$ in Montana. Since the $\mathrm{N}$ recommendation is surprisingly high in Montana, $280 \mathrm{~kg} \mathrm{~N} \mathrm{ha}^{-1}$ was used as the high $\mathrm{N}$ rate at both AREC and NWARC. Phosphorus and potassium were supplied as monoammonium phosphate (11-52-0) and potassium chloride (0-0-60) according to soil test results from each site and year and following the guidelines [25,26]. The $\mathrm{N}$ input from monoammonium phosphate was counted toward $\mathrm{N}$ application, and urea (46-0-0) was applied to bring $\mathrm{N}$ input to the targeted low, medium, and high $\mathrm{N}$ rates. All fertilizers were top-dressed at seven days after emergence at the AREC, and was incorporated prior to planting at the NWARC. Herbicides, fungicides, and insecticides were applied as needed.

\subsection{Grain Yield, Test Weight, and End-Use Quality Analysis}

Plots were harvested after physiological maturity using a Wintersteiger Classic small-plot combine (Wintersteiger Inc., Salt Lake City, UT, USA) at both the AREC and NWARC, and grain yield (Mg ha ${ }^{-1}$ ) and test weight (TW, $\mathrm{kg} \mathrm{hL}^{-1}$ ) were reported on 12 and $13.5 \%$ of moisture basis, respectively. All end-use quality traits were determined at the Wheat Quality Laboratory, University of Idaho, Aberdeen, ID. Grain samples were ground using a Brabender Quadrumat Senior laboratory mill (C.W. Brabender Instruments, Inc., South Hackensack, NJ, USA), and flour yield (FY, \%) was calculated as the percentage of flour produced from the grain. Grain hardness (GH), flour protein content (FP, \%), and flour ash content (FA, \%) were determined using a PerCon Inframatic 8611 Near-infrared Spectroscopy Analyzer (Perten Instruments, Springfield, IL, USA) according to the American Association of Cereal Chemists (AACC) method 39-70, 39-11, and 08-01A, respectively [30]. The contents of flour protein and ash were reported on a $14 \%$ of moisture basis. Ash content indicates how well the flour separates from the bran, and a low ash content is often a high priority among millers to get white flours. Mixograph (National MFG Co., Lincoln, NE, USA) peak time (MPT, min) and height (MPH, cm) reflect the time to achieve optimum mixing and dough strength, respectively, and were determined according to modified AACC method 54-40 with $10 \mathrm{~g}$ of flour. Shorter mixing time is usually preferred for baking. Bread-baking test was conducted according to AACC method 10-10B, and baking loaf volume (LV, $\mathrm{cm}^{3}$ ) was measured by rapeseed displacement. Solvent retention capacity (SRC) with deionized water (water SRC, \%), $5 \%$ sodium carbonate $\left(\mathrm{Na}_{2} \mathrm{CO}_{3} \mathrm{SRC}, \%\right), 5 \%$ lactic acid (lactic acid SRC, \%), and 50\% sucrose (sucrose SRC, \%) is indicative of overall water absorption, damaged starch, gluten strength, and arabinoxylan and partially hydrated gliadin content, respectively [15]. The SRCs were determined according to Guttieri et al. [31] and adjusted to a $14 \%$ of moisture basis. Wet gluten content (WG, \%) and gluten index (GI) were analyzed by Wheat Quality and Carbohydrates Research Laboratory, North 
Dakota State University, according to AACC method 38-12.02 using a Glutomatic system (Perten Instruments, Springfield, IL, USA).

\subsection{Statistical Analysis}

Data from the AREC and NWARC were analyzed separately using the generalized linear mixed model (Pro GLIMMIX) in SAS (version 9.4, SAS Institute Inc., Cary, NC, USA). Fixed effects included drought stress, $\mathrm{N}$ rate, and their interaction, while year, block, and block $\times$ drought stress interaction nested within each year were treated as random effects. To test for differences among fixed effects, the Tukey-Kramer adjustment was applied for multiple comparisons at a significance level of 0.05 . Pearson correlation analyses were performed among end-use quality parameters (Pro CORR). All figures and linear regressions were generated using SigmaPlot (version 13.0, Systat Software, San Jose, CA, USA).

\section{Results}

\subsection{Grain Yield and Test Weight}

Grain yield was gradually enhanced by increasing water availability (i.e., less severe drought stress) in both cultivars (Tables 2 and 3). Compared to the well-watered treatment, mild drought stress resulted in a grain yield loss of 8.7 and $9.3 \%$ in Dayn and Egan, respectively, but the yield reduction was not statistically significant in Dayn. Relative to the zero $\mathrm{N}$ treatment, $\mathrm{N}$ application increased grain yield of Dayn by $2-11 \%$, but this improvement was not statistically significant. Grain yield showed minimal response to $\mathrm{N}$ application in Egan.

Test weight increased with increasing water availability, but tended to decrease with increasing $\mathrm{N}$ rate in both Dayn (Table 2) and Egan (Table 3). No significant difference was observed in TW between the well-watered treatment and mild drought stress or between medium and high $\mathrm{N}$ rates. 
Table 2. End-use quality traits as affected by drought stress treatment and N rate in Dayn at the Aberdeen Research and Extension Center, Aberdeen, ID.

\begin{tabular}{|c|c|c|c|c|c|c|c|c|c|c|c|c|c|c|c|}
\hline \multirow{3}{*}{ Treatment $^{2}$} & \multicolumn{15}{|c|}{ End-Use Quality Trait ${ }^{1}$} \\
\hline & GY & TW & GH & FY & FA & FP & WG & GI & MPT & MPH & WaterSRC & $\begin{array}{c}\mathrm{Na}_{2} \mathrm{CO}_{3} \\
\mathrm{SRC}\end{array}$ & $\begin{array}{l}\text { Lactic acid } \\
\text { SRC }\end{array}$ & Sucrose & RC LV \\
\hline & $\mathrm{Mg} \mathrm{ha}^{-1}$ & $\mathrm{~kg} \mathrm{hL}^{-1}$ & \multicolumn{6}{|c|}{$\%$} & $\min$ & $\mathrm{cm}$ & \multicolumn{3}{|c|}{$\%$} & & $\mathrm{~cm}^{3}$ \\
\hline Severe & $2.1 c^{3}$ & $70.5 \mathrm{~b}$ & 77.4 & $58.7 \mathrm{~b}$ & $0.38 \mathrm{a}$ & $16.4 \mathrm{a}$ & $39.1 \mathrm{a}$ & 85.8 & $4.5 \mathrm{a}$ & $7.8 \mathrm{a}$ & 59.4 & 71.2 & $140 \mathrm{a}$ & $98.6 \mathrm{a}$ & $1363 \mathrm{a}$ \\
\hline Moderate & $5.2 \mathrm{~b}$ & $78.3 \mathrm{a}$ & 77.2 & $60.8 \mathrm{a}$ & $0.34 \mathrm{~b}$ & $12.9 \mathrm{~b}$ & $32.7 \mathrm{~b}$ & 89.0 & $3.7 \mathrm{~b}$ & $7.1 \mathrm{~b}$ & 56.7 & 68.4 & $127 \mathrm{ab}$ & $92.5 \mathrm{ab}$ & $1173 b$ \\
\hline Mild & $6.3 \mathrm{a}$ & $78.8 \mathrm{a}$ & 76.8 & $60.2 \mathrm{a}$ & $0.34 \mathrm{~b}$ & $11.5 \mathrm{c}$ & $30.4 \mathrm{~b}$ & 91.0 & $3.2 \mathrm{bc}$ & $6.8 \mathrm{~b}$ & 55.7 & 68.2 & $115 \mathrm{~b}$ & $89.9 \mathrm{~b}$ & $1054 \mathrm{c}$ \\
\hline Well-watered & $6.9 \mathrm{a}$ & $78.3 \mathrm{a}$ & 79.1 & $59.8 \mathrm{ab}$ & $0.34 \mathrm{~b}$ & $11.3 \mathrm{c}$ & $29.8 \mathrm{~b}$ & 81.3 & $2.9 \mathrm{c}$ & $6.8 \mathrm{~b}$ & 56.1 & 69.1 & $103 \mathrm{~b}$ & $89.7 \mathrm{~b}$ & $1040 \mathrm{c}$ \\
\hline$p$-value & $<0.001$ & $<0.001$ & 0.483 & 0.002 & $<0.001$ & $<0.001$ & 0.002 & 0.121 & $<0.001$ & $<0.001$ & 0.074 & 0.154 & $<0.001$ & 0.018 & $<0.001$ \\
\hline \multicolumn{16}{|l|}{ Soil $\mathrm{N}$ rate } \\
\hline Zero & 4.9 & $78.3 \mathrm{a}$ & $76.0 \mathrm{~b}$ & 59.5 & $0.34 \mathrm{~b}$ & $12.0 \mathrm{~b}$ & $30.2 \mathrm{~b}$ & 87.5 & 3.5 & $6.8 \mathrm{~b}$ & 55.3 & 69.0 & 116 & 91.4 & $1105 \mathrm{~b}$ \\
\hline Low & 5.0 & $76.8 \mathrm{ab}$ & $76.7 \mathrm{~b}$ & 60.0 & $0.35 \mathrm{ab}$ & $13.1 \mathrm{ab}$ & $31.8 \mathrm{ab}$ & 89.0 & 3.6 & $7.1 \mathrm{ab}$ & 56.4 & 69.1 & 123 & 91.3 & $1160 \mathrm{ab}$ \\
\hline Medium & 5.5 & $75.8 \mathrm{ab}$ & $78.3 \mathrm{ab}$ & 60.0 & $0.36 \mathrm{a}$ & $13.3 \mathrm{a}$ & $33.7 \mathrm{a}$ & 84.6 & 3.5 & $7.1 \mathrm{ab}$ & 57.1 & 69.6 & 119 & 93.3 & $1168 \mathrm{ab}$ \\
\hline High & 5.3 & $75.4 \mathrm{~b}$ & $79.4 \mathrm{a}$ & 60.0 & $0.36 \mathrm{a}$ & $13.6 \mathrm{a}$ & $34.7 \mathrm{a}$ & 86.3 & 3.6 & $7.3 \mathrm{a}$ & 58.3 & 68.8 & 123 & 93.0 & $1186 a$ \\
\hline$p$-value & 0.317 & 0.043 & 0.005 & 0.418 & $<0.001$ & 0.003 & 0.003 & 0.392 & 0.901 & 0.018 & 0.109 & 0.484 & 0.101 & 0.054 & 0.049 \\
\hline
\end{tabular}

${ }^{1}$ GY, grain yield; TW, test weight; GH, grain hardness; FY, flour yield; FA, flour ash content; FP, flour protein content; WG, wet gluten content; GI, gluten index; MPT and MPH, mixograph peak time and height; SRC, solvent retention capacity; LV, baking loaf volume. ${ }^{2}$ Drought stress $\times \mathrm{N}$ rate interaction was not significant in any parameter. ${ }^{3}$ Different letters following means $(n=8)$ indicate significant differences among drought stress treatments or $\mathrm{N}$ rates at $\alpha=0.05$ 
Table 3. End-use quality traits as affected by drought stress treatment and N rate in Egan at the Northwest Agricultural Research Center, Kalispell, MT.

\begin{tabular}{|c|c|c|c|c|c|c|c|c|c|c|c|c|c|c|c|}
\hline \multirow{3}{*}{ Treatment $^{2}$} & \multicolumn{15}{|c|}{ End-Use Quality Trait ${ }^{1}$} \\
\hline & GY & TW & GH & FY & FA & FP & WG & GI & MPT & MPH & Water SRC & $\begin{array}{c}\mathrm{Na}_{2} \mathrm{CO}_{3} \\
\mathrm{SRC}\end{array}$ & $\begin{array}{l}\text { Lactic acid } \\
\text { SRC }\end{array}$ & $\begin{array}{l}\text { Sucrose } \\
\text { SRC }\end{array}$ & LV \\
\hline & $\mathrm{Mg} \mathrm{ha}^{-1}$ & $\mathrm{~kg} \mathrm{hL}^{-1}$ & \multicolumn{6}{|c|}{$\%$} & $\min$ & $\mathrm{cm}$ & \multicolumn{4}{|c|}{$\%$} & $\mathrm{~cm}^{3}$ \\
\hline Severe & $3.6 c^{3}$ & $74.7 \mathrm{c}$ & $84.2 \mathrm{ab}$ & $53.3 \mathrm{~b}$ & 0.65 & 15.5 & 39.7 & 83.5 & $5.4 \mathrm{a}$ & $6.9 \mathrm{~b}$ & $70.1 \mathrm{a}$ & 93.1 & $118 \mathrm{~b}$ & 111 & $1069 \mathrm{c}$ \\
\hline Moderate & $4.4 \mathrm{~b}$ & $76.0 \mathrm{~b}$ & $85.0 \mathrm{a}$ & $54.7 \mathrm{ab}$ & 0.64 & 15.7 & 40.5 & 85.6 & $4.5 \mathrm{~b}$ & $7.4 \mathrm{a}$ & $69.6 \mathrm{ab}$ & 92.5 & $124 \mathrm{ab}$ & 111 & $1130 \mathrm{~b}$ \\
\hline Mild & $4.7 \mathrm{~b}$ & $76.2 \mathrm{ab}$ & $83.7 \mathrm{ab}$ & $54.4 \mathrm{a}$ & 0.64 & 15.6 & 41.4 & 88.0 & $4.3 \mathrm{~b}$ & $7.7 \mathrm{a}$ & $69.2 \mathrm{ab}$ & 92.4 & $129 a$ & 112 & $1182 \mathrm{a}$ \\
\hline Well-watered & $5.2 \mathrm{a}$ & $76.4 \mathrm{a}$ & $82.9 \mathrm{~b}$ & $55.3 \mathrm{a}$ & 0.64 & 15.5 & 40.5 & 86.5 & $3.9 \mathrm{~b}$ & $7.6 \mathrm{a}$ & $68.8 \mathrm{~b}$ & 92.8 & $131 \mathrm{a}$ & 112 & $1162 \mathrm{ab}$ \\
\hline P value & $<0.001$ & $<0.001$ & 0.030 & $<0.001$ & 0.058 & 0.658 & 0.148 & 0.064 & $<0.001$ & $<0.001$ & 0.002 & 0.925 & 0.005 & 0.329 & $<0.001$ \\
\hline \multicolumn{16}{|l|}{ Soil $\mathrm{N}$ rate } \\
\hline Zero & 4.4 & $76.3 \mathrm{a}$ & $76.4 \mathrm{~b}$ & $57.1 \mathrm{a}$ & $0.62 \mathrm{c}$ & $14.2 \mathrm{~b}$ & $35.9 \mathrm{~b}$ & $95.6 \mathrm{a}$ & 4.7 & $7.3 \mathrm{~b}$ & $68.6 \mathrm{~b}$ & 93.9 & $136 \mathrm{a}$ & $113 \mathrm{a}$ & $1113 b$ \\
\hline Low & 4.4 & $75.9 \mathrm{~b}$ & $85.6 \mathrm{a}$ & $53.7 \mathrm{~b}$ & $0.64 \mathrm{~b}$ & $15.7 \mathrm{a}$ & $41.1 \mathrm{a}$ & $85.2 \mathrm{~b}$ & 4.6 & $7.6 \mathrm{a}$ & $69.0 \mathrm{~b}$ & 91.8 & $124 \mathrm{~b}$ & $111 \mathrm{~b}$ & $1123 b$ \\
\hline Medium & 4.5 & $75.7 \mathrm{bc}$ & $87.1 \mathrm{a}$ & $53.6 \mathrm{~b}$ & $0.66 \mathrm{a}$ & $16.2 \mathrm{a}$ & $42.5 \mathrm{a}$ & $81.0 \mathrm{~b}$ & 4.5 & $7.4 \mathrm{ab}$ & $70.1 \mathrm{a}$ & 93.0 & $121 \mathrm{~b}$ & $111 \mathrm{ab}$ & $1129 b$ \\
\hline High & 4.6 & $75.5 c$ & $86.7 \mathrm{a}$ & $53.4 \mathrm{~b}$ & $0.65 \mathrm{a}$ & $16.2 \mathrm{a}$ & $42.7 \mathrm{a}$ & $81.8 \mathrm{~b}$ & 4.4 & $7.4 \mathrm{ab}$ & $69.9 \mathrm{a}$ & 92.1 & $123 \mathrm{~b}$ & $111 \mathrm{~b}$ & $1178 \mathrm{a}$ \\
\hline$p$-value & 0.293 & $<0.001$ & $<0.001$ & $<0.001$ & $<0.001$ & $<0.001$ & $<0.001$ & $<0.001$ & 0.233 & 0.004 & $<0.001$ & 0.101 & $<0.001$ & 0.005 & 0.002 \\
\hline
\end{tabular}

${ }^{1}$ GY, grain yield; TW, test weight; GH, grain hardness; FY, flour yield; FA, flour ash content; FP, flour protein content; WG, wet gluten content; GI, gluten index; MPT and MPH, mixograph peak time and height; SRC, solvent retention capacity; LV, baking loaf volume. ${ }^{2}$ Drought stress $\times \mathrm{N}$ rate interaction was not significant in any parameter. ${ }^{3}$ Different letters following means $(n=8)$ indicate significant differences among drought stress treatments or $\mathrm{N}$ rates at $\alpha=0.05$ 


\subsection{Milling Quality}

Dayn had greater GH under the high $\mathrm{N}$ rate than the low and zero rates, but it was not affected by drought stress (Table 2). Its FY was greater under mild and moderate drought stress than severe drought stress, but did not differ among N rates. Greater FA was observed in Dayn under severe drought stress than the other three drought stress levels, and the medium and high $\mathrm{N}$ rates produced greater FA than the zero $\mathrm{N}$ rate.

Egan showed a higher GH under moderate drought stress than the well-watered treatment, but its FA did not differ among drought stress levels (Table 3). Nitrogen application generally increased both GH and FA. Egan's FY was greater under the well-watered treatment and mild drought stress than severe drought stress, while the zero $\mathrm{N}$ rate produced a higher $\mathrm{FY}$ than the other three rates.

\subsection{Flour Protein, Wet Gluten, and Gluten Index}

Dayn's FP and WG generally increased with drought stress severity (Table 2), but those of Egan were not affected by drought stress (Table 3). Application of $\mathrm{N}$ (e.g., the medium and high $\mathrm{N}$ rates) increased both FP and WG in both cultivars, especially when compared with the zero N rate. Dayn's GI was not affected by drought stress or $\mathrm{N}$ rate. In Egan, GI was not affect by drought stress, whereas the zero $\mathrm{N}$ rate produced greater $\mathrm{GI}$ than the other three $\mathrm{N}$ rates.

\subsection{Dough Rheological Properties}

In both Dayn and Egan, MPT under severe drought stress was the greatest among the four drought stress levels, but it was not affected by $\mathrm{N}$ rate in either cultivar (Tables 2 and 3). Dayn also showed greater MPH under severe drought stress relative to the other drought stress levels, but the opposite trend was observed in Egan. In both Dayn and Egan, lower MPH was measured under the zero $\mathrm{N}$ rate relative to other rates.

\subsection{Solvent Retention Capacity}

Dayn had greater lactic acid and sucrose SRCs under severe drought stress compared to mild drought stress and well-watered conditions (Table 2). Its water and $\mathrm{Na}_{2} \mathrm{CO}_{3} \mathrm{SRC}$ s were not influenced by drought stress, and none of its SRCs were notably affected by $\mathrm{N}$ rate.

Egan showed greater water SRC under severe drought stress than the well-watered treatment, and lactic acid SRC under mild drought stress and well-watered conditions was greater than severe drought stress (Table 3). Neither $\mathrm{Na}_{2} \mathrm{CO}_{3}$ or sucrose SRC was influenced by drought stress. Egan produced greater water SRC under medium and high $\mathrm{N}$ rates than the zero and low $\mathrm{N}$ rates. Its lactic acid and sucrose SRCs under the zero $\mathrm{N}$ rate were generally greater than treatments with $\mathrm{N}$ application, whereas $\mathrm{Na}_{2} \mathrm{CO}_{3} \mathrm{SRC}$ was not affected by $\mathrm{N}$ rate.

\subsection{Correlations among End-Use Quality Traits}

Flour protein content linearly decreased with increasing grain yield in Dayn (Figure 2). However, Egan's FP remained relatively consistent as its grain yield increased from 2 to $7 \mathrm{Mg} \mathrm{ha}^{-1}$.

In both Dayn and Egan, FA was positively correlated with GH, but negatively correlated with FY (Tables 4 and 5). Strong correlations (e.g., $r>0.7$ ) between FP and WG were shown in both cultivars. Dayn' FP was positively correlated with MPT, MPH, all four SRCs, and LV, whereas Egan's FP showed a negative correlation with lactic acid SRC and a lack of correlation with LV. Both cultivars' GIs were negatively correlated with WG, but not correlated with LV in either cultivar. Positive correlations were found between lactic acid SRC and LV, as well as between water SRC and $\mathrm{Na}_{2} \mathrm{CO}_{3} \mathrm{SRC}$ in both cultivars. 
Table 4. Pearson correlation coefficients $(n=128)$ among end-use quality traits in Dayn at the Aberdeen Research and Extension Center, Aberdeen, ID.

\begin{tabular}{|c|c|c|c|c|c|c|c|c|c|c|c|c|c|}
\hline $\begin{array}{c}\text { End-Use } \\
\text { Quality Traits }{ }^{1}\end{array}$ & $\mathrm{GH}^{2}$ & FY & FA & FP & WG & GI & MPT & MPH & $\begin{array}{l}\text { Water } \\
\text { SRC }\end{array}$ & $\begin{array}{c}\mathrm{Na}_{2} \mathrm{CO}_{3} \\
\text { SRC }\end{array}$ & $\begin{array}{l}\text { Lactic Acid } \\
\text { SRC }\end{array}$ & $\begin{array}{l}\text { Sucrose } \\
\text { SRC }\end{array}$ & LV \\
\hline TW & -0.04 & $0.47^{* *}$ & $-0.48^{* *}$ & $-0.47^{* *}$ & $-0.80^{* *}$ & 0.22 & $-0.31^{* *}$ & $-0.39 * *$ & $-0.37^{* *}$ & $-0.39 * *$ & $-0.59 * *$ & -0.64 ** & $-0.32 * *$ \\
\hline $\mathrm{GH}$ & & 0.09 & $0.29^{* *}$ & $0.24 * *$ & 0.08 & $-0.36 * *$ & $-0.25 * *$ & $0.29^{* *}$ & 0.11 & -0.13 & -0.10 & 0.00 & $0.20 *$ \\
\hline FY & & & $-0.24 * *$ & -0.14 & -0.27 * & 0.21 & -0.11 & 0.02 & -0.36 ** & $-0.61^{* *}$ & -0.14 & $-0.55 * *$ & -0.02 \\
\hline FA & & & & $0.89^{* *}$ & $0.65^{* *}$ & $-0.39 * *$ & $0.56^{* *}$ & $0.67^{* *}$ & $0.39^{* *}$ & $0.33^{* *}$ & $0.41^{* *}$ & $0.48^{* *}$ & $0.75^{* *}$ \\
\hline FP & & & & & $0.88^{* *}$ & -0.24 & $0.68 * *$ & $0.80 * *$ & $0.43^{* *}$ & $0.30 *$ & $0.81 * *$ & $0.65^{* *}$ & $0.91 * *$ \\
\hline WG & & & & & & $-0.43^{* *}$ & $0.55^{* *}$ & $0.77^{* *}$ & 0.42 ** & 0.27 * & $0.72 * *$ & $0.65^{* *}$ & $0.71^{* *}$ \\
\hline GI & & & & & & & 0.26 * & $-0.30 *$ & -0.17 & -0.22 & 0.03 & -0.21 & -0.11 \\
\hline MPT & & & & & & & & $0.44^{* *}$ & 0.10 & 0.02 & $0.65^{* *}$ & $0.33 * *$ & $0.62 * *$ \\
\hline Water SRC & & & & & & & & & & $0.47^{* *}$ & $0.43 * *$ & $0.55 * *$ & $0.33 * *$ \\
\hline $\mathrm{Na}_{2} \mathrm{CO}_{3} \mathrm{SRC}$ & & & & & & & & & & & $0.36^{* *}$ & $0.73 * *$ & $0.26 *$ \\
\hline Lactic acid SRC & & & & & & & & & & & & $0.73^{* *}$ & $0.72 * *$ \\
\hline Sucrose SRC & & & & & & & & & & & & & $0.61 * *$ \\
\hline
\end{tabular}

${ }^{1}$ TW, test weight; GH, grain hardness; FY, flour yield; FA, flour ash content; FP, flour protein content; WG, wet gluten content; GI, gluten index; MPT and MPH, mixograph peak time and

height; SRC, solvent retention capacity; LV, baking loaf volume. ${ }^{2 *}$ and ${ }^{* *}$ indicate significance at $\alpha=0.05$ and 0.01 , respectively.

Table 5. Pearson correlation coefficients $(n=128)$ among end-use quality traits in Egan at the Northwest Agricultural Research Center, Kalispell, MT.

\begin{tabular}{|c|c|c|c|c|c|c|c|c|c|c|c|c|c|}
\hline $\begin{array}{c}\text { End-Use } \\
\text { Quality Traits } 1\end{array}$ & $\mathrm{GH}^{2}$ & FY & FA & FP & WG & GI & MPT & MPH & $\begin{array}{l}\text { Water } \\
\text { SRC }\end{array}$ & $\begin{array}{c}\mathrm{Na}_{2} \mathrm{CO}_{3} \\
\text { SRC }\end{array}$ & $\begin{array}{l}\text { Lactic Acid } \\
\text { SRC }\end{array}$ & $\begin{array}{l}\text { Sucrose } \\
\text { SRC }\end{array}$ & LV \\
\hline TW & $-0.38^{* *}$ & $0.49 * *$ & $0.87^{* *}$ & -0.10 & $0.24 * *$ & $0.44^{* *}$ & $-0.88^{* *}$ & $0.79 * *$ & $0.70 * *$ & $0.85 * *$ & $-0.73 * *$ & $0.85^{* *}$ & $-0.71^{* *}$ \\
\hline GH & & $-0.66^{* *}$ & $0.59 * *$ & $0.79 * *$ & $0.75^{* *}$ & $-0.85 * *$ & -0.03 & 0.14 & $0.65 * *$ & $-0.41 * *$ & $-0.71 * *$ & $-0.58^{* *}$ & 0.08 \\
\hline FY & & & $-0.34 * *$ & $-0.61^{* *}$ & $-0.59 * *$ & $0.60 * *$ & $-0.34^{* *}$ & $0.26^{*}$ & $-0.43^{* *}$ & $0.59 * *$ & $0.55^{* *}$ & $0.48^{* *}$ & -0.06 \\
\hline FP & & & & & $0.73^{* *}$ & $-0.63 * *$ & -0.10 & 0.13 & $0.22 *$ & 0.00 & $-0.25^{* *}$ & -0.04 & 0.05 \\
\hline WG & & & & & & -0.53 ** & -0.41 ** & $0.46^{* *}$ & $0.48 * *$ & $0.29 * *$ & $-0.46^{* *}$ & $0.31 * *$ & $-0.22 *$ \\
\hline GI & & & & & & & $-0.26^{* *}$ & $0.25^{* *}$ & 0.09 & $0.32 * *$ & -0.02 & $0.40^{* *}$ & -0.18 \\
\hline MPT & & & & & & & & $-0.88^{* *}$ & $-0.69^{* *}$ & $-0.77^{* *}$ & $0.68 * *$ & $-0.82 * *$ & $0.62 * *$ \\
\hline MPH & & & & & & & & & $0.60 * *$ & $0.65^{* *}$ & $-0.58 * *$ & $0.74 * *$ & $-0.46^{* *}$ \\
\hline Water SRC & & & & & & & & & & $0.82 * *$ & $-0.88^{* *}$ & $0.72 * *$ & $-0.78^{* *}$ \\
\hline $\mathrm{Na}_{2} \mathrm{CO}_{3} \mathrm{SRC}$ & & & & & & & & & & & $-0.86^{* *}$ & $0.86 * *$ & $-0.83^{* *}$ \\
\hline Lactic acid SRC & & & & & & & & & & & & $-0.72 * *$ & $0.87^{* *}$ \\
\hline Sucrose SRC & & & & & & & & & & & & & $-0.75^{* *}$ \\
\hline
\end{tabular}

${ }^{1}$ TW, test weight; GH, grain hardness; FY, flour yield; FA, flour ash content; FP, flour protein content; WG, wet gluten content; GI, gluten index; MPT and MPH, mixograph peak time and height; SRC, solvent retention capacity; LV, baking loaf volume. ${ }^{2 *}$ and ${ }^{* *}$ indicate significance at $\alpha=0.05$ and 0.01 , respectively. 


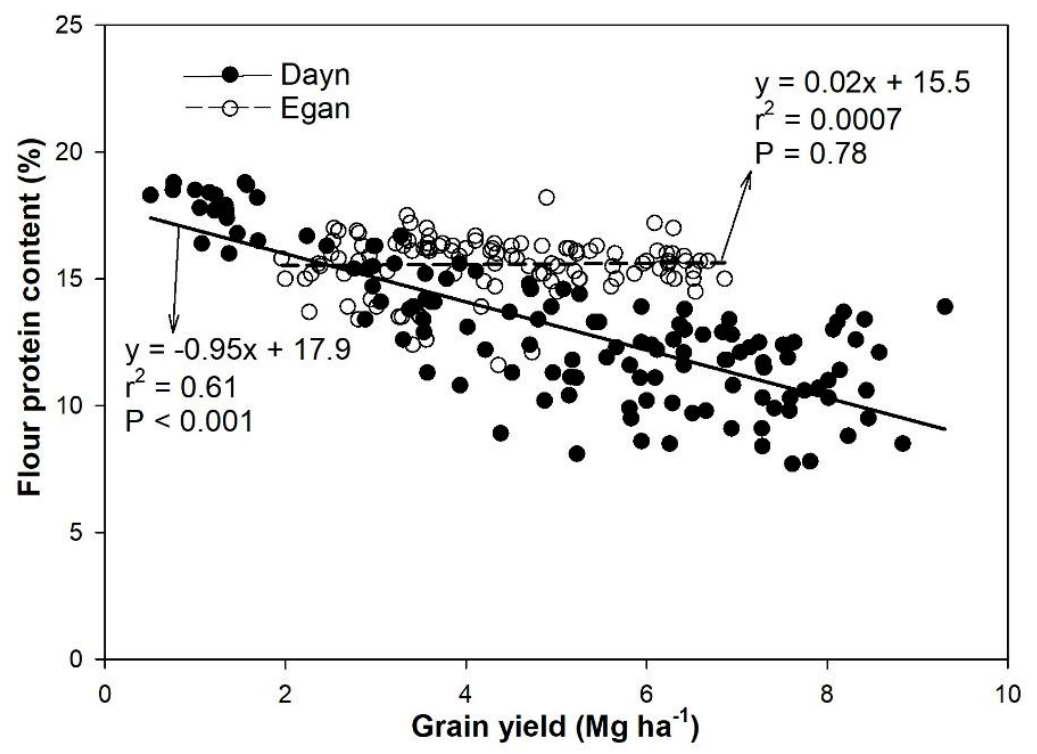

Figure 2. Relationships between grain yield and flour protein content in Dayn $(n=128)$ and Egan $(n=128)$.

\section{Discussion}

\subsection{Effects of Drought Stress on Grain Yield and Flour End-Use Quality}

The current study found that grain yield generally decreased with the severity of drought stress in both Dayn and Egan. Mild drought stress (i.e., $75 \% \mathrm{ET}_{\mathrm{C}}$ replenishment or $25 \%$ of reduction in irrigation throughout the growing season) resulted in approximately $9 \%$ of grain yield reduction relative to the well-watered treatment (i.e., $100 \% \mathrm{ET}_{\mathrm{C}}$ replenishment), but the yield reduction was not statistically significant in Dayn, suggesting mild drought stress or well-regulated deficit irrigation has minimal influence on wheat grain yield [28,32]. In addition, most end-use quality parameters were notably affected by drought stress, but few parameters differed between mild drought stress and the well-watered treatment, suggesting that mild drought stress throughout the entire season does not significantly affect flour end-use quality.

Flour or grain protein content and grain yield are often negatively associated, possibly due to the dilution effect $[15,20,22]$. Similar results were observed in Dayn in the current study; however, Egan was able to maintain relatively constant FP and WG regardless of improved grain yield at less severe drought stress. Egan carries a gene for high grain protein, Gpc-B1, which was introgressed from wild emmer wheat (Triticum turgidum ssp. Dicoccoides) [13]. In genotypes carrying the Gpc-B1 gene, increased levels of soluble protein and amino acids in flag leaves at anthesis and improved translocation from leaves to developing seeds have been observed [33-35]. Under optimal irrigation and fertilization conditions, genotypes carrying the Gpc-B1 gene could achieve both optimal grain yield and protein [12], but there is lack of information from previous studies on their performance under suboptimal conditions. The current study indicates that Egan carrying the Gpc-B1 gene, is able to produce high protein (15.5-15.7\%) at various water regimes, which surpasses the premium market quality of grain protein content for hard red spring wheat (i.e., 14\%) in the U.S.

\subsection{Effects of N Application on Grain Yield and Flour End-Use Quality}

Although current fertilizer guidelines in southern Idaho and Montana suggest $\mathrm{N}$ fertilization for spring wheat in the current study $[25,26]$, inevident grain yield response to $\mathrm{N}$ application was observed. Similar trend also occurred for the aboveground biomass and $\mathrm{N}$ concentration in straw at harvest (data not shown). These results indicate that continuous $\mathrm{N}$ fertilization has built up soil $\mathrm{N}$ fertility and soil residual $\mathrm{N}$ might be sufficient for optimum grain yield. Furthermore, $\mathrm{N}$ uptake or $\mathrm{N}$ 
use efficiency has been genetically increased by breeding efforts for improving grain yield over the last a few decades, so the $\mathrm{N}$ requirement for optimal yield in recently released cultivars may need to be adjusted accordingly [36,37]. A recent study also reported that surplus $\mathrm{N}$ beyond $80 \mathrm{~kg} \mathrm{~N} \mathrm{ha}^{-1}$, which is similar to the medium $\mathrm{N}$ rate in the current study, failed to offer further benefits to grain yield and quality [38]. Although there is a lack of grain yield response to applied N, most end-use quality traits were notably affected by $\mathrm{N}$ rate, especially between treatments with and without $\mathrm{N}$ addition (i.e., zero $\mathrm{N}$ rate).

Flour produced with high $\mathrm{N}$ availability (e.g., medium and high $\mathrm{N}$ rates) absorbed more water (i.e., higher water SRC) than low $\mathrm{N}$ availability (e.g., low and zero $\mathrm{N}$ rates), especially in Egan, which agrees with findings of Boehm et al. [39] and Guttieri et al. [15]. It has been reported that approximately $90 \%$ of the variation in water absorption can be explained by differences in protein and damaged starch contents $[40,41]$. In the current study, increased water absorption is likely due to increased FP following $\mathrm{N}$ application as well as changes in the composition of flour protein. Wieser and Seilmeier [24] observed increased proportions of hydrophilic proteins (e.g., $\omega$-gliadins and high-molecular-weight subunits of glutenin) and reduced proportions of hydrophobic proteins (e.g., $\gamma$-gliadin and low-molecular-weight subunits of glutenin) at increased $\mathrm{N}$ supply. In addition, damaged starch, measured by $\mathrm{Na}_{2} \mathrm{CO}_{3}$ $\mathrm{SRC}$, is more hydrophilic than undamaged starch and absorbs a greater amount of water [42,43]. These findings may explain the positive correlations between water SRC and $\mathrm{Na}_{2} \mathrm{CO}_{3} \mathrm{SRC}$ in the current study.

\subsection{Relationships among End-Use Quality Parameters}

In the current study, GI showed inconsistent correlations with FP and lacked correlation with LV, which agrees with findings of Mutwali et al. [44]. It should be thus discreet when using GI for evaluating flour quality $[45,46]$. However, as one of the gluten strength parameters, lactic acid SRC was closely correlated with LV, which agrees with findings of Li et al. [47] and Xiao et al. [48]. Therefore, lactic acid SRC may be used as a reliable indicator for evaluating gluten strength and predicting baking loaf volume, especially when the amount of flour samples is limited [48].

Flour protein is one of the most determinant parameters of wheat end-use quality and has been found to be positively correlated with mixograph parameters (e.g., MPT and MPH), SRCs, and LV [47,48]. However, Egan's FP showed a negative correlation with gluten strength (i.e., lactic acid SRC) and a lack of correlation with LV. This may be attributable to Egan's high FP ( $>15 \%)$, as Rharrabti et al. [49] found a negative correlation between grain protein and gluten strength when protein content is high (e.g., 13-16\%). These results suggest that the role of FP in determining end-use quality varies with protein content levels and might be less dominant when FP is high. Besides the quantity of flour protein, gluten strength and bread-making performance are also determined by the composition of flour protein, especially the high molecular weight subunits of glutenins $[14,16]$. Despite the increase in grain protein content due to the introgression of the Gpc-B1 gene (in Egan) [12,33-35], little information is available regarding effects of this gene on gluten properties. Research in such areas may be necessary and could greatly facilitate breeding programs for improving grain protein content and gluten strength simultaneously.

\section{Conclusions}

The current study found that mild drought stress (i.e., a $25 \%$ of reduction in irrigation throughout growing season) had minimal effects on wheat grain yield and flour end-use quality in the two evaluated spring wheat cultivars, Dayn and Egan. Most end-use quality traits were affected by $\mathrm{N}$ rate in both cultivars, but $\mathrm{N}$ rates above the low rate (i.e., $168 \mathrm{~kg} \mathrm{~N} \mathrm{ha}^{-1}$ ) offered minimal further improvement on flour end-use quality. Among all the end-use parameters, lactic acid SRC may serve as a reliable indicator of grain quality for hard spring wheat. Results from the current study could facilitate the development of irrigation and fertilization guidelines targeting at grain quality, as well as provide reference on the reliability of different parameters for evaluating flour end-use quality. 
Author Contributions: R.Y. performed the experiments, collected and analyzed the data, and developed the manuscript. X.L. designed and performed the experiments, collected the data, and developed the manuscript. J.A.T. designed and performed the experiments, collected the data, and contributed to the manuscript development. O.S.W. designed the experiments and contributed to the manuscript development. K.O. analyzed the collected samples and interpreted the results. Q.L. provided constructive suggestions on sample analysis.

Funding: This research was funded by USDA-NIFA Western SARE (grant no. SW16-031) and USDA-NIFA Hatch Project (grant no. 1006598).

Acknowledgments: The authors would like to acknowledge Howard Neibling, Randy Gamble, Chad Jackson, Karissa Ramos, Paulina Pelayo, Cindrie Lowder, Pamela Flores, and Rosa Esquivias, for their contributions to experimental setting and data collection.

Conflicts of Interest: The authors declare no conflict of interest.

\section{References}

1. FAOSTAT Database. Available online: http:/ / faostat3.fao.org/ (accessed on 15 February 2018).

2. Shewry, P.R. Wheat. J. Exp. Bot. 2009, 60, 1537-1553. [CrossRef] [PubMed]

3. Shiferaw, B.; Smale, M.; Braun, H.J.; Duveiller, E.; Reynolds, M.; Muricho, G. Crops that feed the world 10. Past successes and future challenges to the role played by wheat in global food security. Food Secur. 2013, 5, 291-317. [CrossRef]

4. Pasha, I.; Anjum, F.M.; Morris, C.F. Grain Hardness: A major determinant of wheat quality. Food Sci. Technol. Int. 2010, 16, 511-522. [CrossRef] [PubMed]

5. Caffe-Treml, M.; Glover, K.D.; Krishnan, P.G.; Hareland, G.A.; Bondalapati, K.D.; Stein, J. Effect of wheat genotype and environment on relationships between dough extensibility and breadmaking quality. Cereal Chem. 2011, 88, 201-208. [CrossRef]

6. Carson, G.R.; Edwards, N.M. Criteria of wheat and flour quality. In Wheat: Chemistry and Technology, 4th ed.; Khan, K., Shewry, P.R., Eds.; AACC International: Saint Paul, MN, USA, 2009; pp. 97-118. ISBN 978.

7. Dencic, S.; Mladenov, N.; Kobilkjski, B. Effects of genotype and environment on breadmaking quality in wheat. Int. J. Plant Prod. 2011, 5, 71-82. [CrossRef]

8. Graybosch, R.A.; Peterson, C.J.; Shelton, D.R.; Baezinger, P.S. Genotypic and environmental modification of wheat flour protein composition in relation to end-use quality. Crop Sci. 1996, 36, 296-300. [CrossRef]

9. Ma, W.; Appels, R.; Békés, F.; Larroque, O.R.; Morell, M.K.; Gale, K.R. Genetic characterization of dough rheological properties in a wheat doubled haploid population: Additive genetic effects and epistatic interactions. Theor. Appl. Genet. 2005, 111, 410-422. [CrossRef] [PubMed]

10. Peterson, C.J.; Graybosch, R.A.; Shelton, D.R.; Baezinger, P.S. Baking quality of hard winter wheat: Response of cultivars to environment in the Great Plains. Euphytica 1998, 100, 157-162. [CrossRef]

11. Yong, Z.; He, Z.; Ye, G.; Aimin, Z.; Van Ginkel, M. Effect of environment and genotype on bread-making quality of spring-sown spring wheat cultivars in China. Euphytica 2004, 139, 75-83. [CrossRef]

12. Brevis, J.C.; Morris, C.F.; Manthey, F.; Dubcovsky, J. Effect of the grain protein content locus Gpc-B1 on bread and pasta quality. J. Cereal Sci. 2010, 51, 357-365. [CrossRef]

13. Blake, N.K.; Stougaard, R.N.; Bohannon, B.; Weaver, D.K.; Heo, H.-Y.; Lamb, P.F.; Nash, D.; Wichman, D.M.; Kephart, K.D.; Miller, J.H.; et al. Registration of 'Egan' wheat with resistance to orange wheat blossom midge. J. Plant Regist. 2014, 8, 298-302. [CrossRef]

14. Payne, P.I.; Nigtingale, M.A.; Krattiger, A.F.; Holt, L.M. The relationship between HMW glutenin subunit composition and the bread-making quality of British-grown wheat varieties. J. Sci. Food Agric. 1987, 40, 51-65. [CrossRef]

15. Guttieri, M.J.; McLean, R.; Stark, J.C.; Souza, E. Managing irrigation and nitrogen fertility of hard spring wheats for optimum bread and noodle quality. Crop Sci. 2005, 45, 2049-2059. [CrossRef]

16. Johansson, E.; Prieto-Linde, M.L.; Jonsson, J.O. Effects of wheat cultivar and nitrogen application on storage protein composition and breadmaking quality. Cereal Chem. 2001, 78, 19-25. [CrossRef]

17. Johansson, E.; Prieto-Linde, M.L.; Svensson, G. Influence of nitrogen application rate and timing on grain protein composition and gluten strength in Swedish wheat cultivars. J. Plant Nutr. Soil Sci. 2004, 167, 345-350. [CrossRef] 
18. Saint Pierre, C.; Peterson, C.J.; Ross, A.S.; Ohm, J.-B.; Verhoeven, M.C.; Larson, M.; Hoefer, B. White wheat grain quality changes with genotype, nitrogen fertilization, and water stress. Agron. J. 2008, 100, 414-420. [CrossRef]

19. Saint Pierre, C.; Peterson, C.J.; Ross, A.S.; Ohm, J.-B.; Verhoeven, M.C.; Larson, M.; Hoefer, B. Winter wheat genotypes under different levels of nitrogen and water stress: Changes in grain protein composition. J. Cereal Sci. 2008, 47, 407-416. [CrossRef]

20. Guttieri, M.J.; Ahmad, R.; Stark, J.C.; Souza, E. End-use quality of six hard red spring wheat cultivars at different irrigation levels. Crop Sci. 2000, 40, 631-635. [CrossRef]

21. Guzmán, C.; Autrique, J.E.; Mondal, S.; Singh, R.P.; Govindan, V.; Morales-Dorantes, A.; Posadas-Romano, G.; Crossa, J.; Ammar, K.; Peña, R.J. Response to drought and heat stress on wheat quality, with special emphasis on bread-making quality, in durum wheat. Field Crop. Res. 2016, 186, 157-165. [CrossRef]

22. Zeleke, K.T.; Nendel, C. Analysis of options for increasing wheat (Triticum aestivum L.) yield in south-eastern Australia: The role of irrigation, cultivar choice and time of sowing. Agric. Water Manag. 2016, 166, 139-148. [CrossRef]

23. Ozturk, A.; Aydin, F. Effect of water stress at various growth stages on some quality characteristics of winter wheat. J. Agron. Crop Sci. 2004, 190, 93-99. [CrossRef]

24. Wieser, H.; Seilmeier, W. The influence of nitrogen fertilization on quantities and proportions of different protein types in wheat flour. J. Sci. Food Agric. 1998, 76, 49-55. [CrossRef]

25. Brown, B.; Stark, J.C.; Westermann, D.T. Southern Idaho Fertilizer Guide-Irrigated Spring Wheat; University of Idaho: Moscow, Russia, 2001.

26. Jacobsen, J.; Jackson, G.; Jones, C. Fertilizer Guidelines for Montana Crops; Montana State University Extension Services: Bozeman, MT, USA, 2005.

27. Allen, R.G.; Pereira, L.S.; Raes, D.; Smith, M. Crop Evapotranspiration-Guidelines for Computing Crop Water Requirements; FAO: Rome, Italy, 1998.

28. Torrion, J.A.; Stougaard, R.N. Impacts and limits of irrigation water management on wheat yield and quality. Crop Sci 2018, 57, 3239-3251. [CrossRef]

29. Zadoks, J.C.; Chang, T.T.; Konzak, C.F. A decimal code for the growth stages of cereals. Weed Res. 1974, 14, 415-421. [CrossRef]

30. AACC International. Approved Methods of Analysis, 10th ed.; AACC International: Saint Paul, MN, USA, 2000; ISBN 9781891127120.

31. Guttieri, M.J.; Becker, C.; Souza, E.J. Application of wheat meal solvent retention capacity tests within soft wheat breeding populations. Cereal Chem. 2004, 81, 261-266. [CrossRef]

32. Kang, S.; Zhang, L.; Ling, Y.; Hu, X.; Cai, H.; Gu, B. Effects of limited irrigation on yield and water use efficiency of winter wheat in the loess plateau of China. Agric. Water Manag. 2002, 55, 203-216. [CrossRef]

33. Brevis, J.C.; Dubcovsky, J. Effects of the chromosome region including the grain protein content locus Gpc-B1 on wheat grain and protein yield. Crop Sci. 2010, 50, 93-104. [CrossRef]

34. Uauy, C.; Distelfeld, A.; Fahima, T.; Blechl, A.; Dubcovsky, J. A NAC gene regulating senescence improves grain protein, zinc, and iron content in wheat. Science 2006, 314, 1298-1301. [CrossRef] [PubMed]

35. Uauy, C.; Brevis, J.C.; Dubcovsky, J. The high grain protein content gene GPC-B1 accelerated senescence and has pleiotropic effects on protein content in wheat. J. Exp. Bot. 2006, 57, 2785-2794. [CrossRef] [PubMed]

36. Sadras, V.O.; Hayman, P.; Rodriguez, D.; Monjardino, M.; Bielich, M.; Unkovich, M.; Mudge, B.; Wang, E. Interactions between water and nitrogen in Australian cropping systems: Physiological, agronomic, economic, breeding and modelling perspectives. Crop Pasture Sci. 2014, 67, 1019-1053. [CrossRef]

37. Hoogmoed, M.; Sadras, V.O. Water stress scatters nitrogen dilution curves in wheat. Front. Plant Sci. 2018, 9, 406. [CrossRef] [PubMed]

38. Klikocka, H.; Cybulska, M.; Barczak, B.; Narolski, B.; Szostak, B.; Kobiałka, A.; Nowak, A.; Wójcik, E. The effect of sulphur and nitrogen on grain yield and technological quality of spring wheat. Plant Soil Environ. 2016, 62, 230-236. [CrossRef]

39. Boehm, D.J.; Berzonsky, W.A.; Bhattacharya, M. Influence of nitrogen fertilizer treatments on spring wheat (Triticum aestivum L.) flour characteristics and effect on fresh and frozen dough quality. Cereal Chem. 2004, 81, 51-54. [CrossRef]

40. Greer, E.N.; Stewart, B.A. The water absorption of wheat flour: Relative effects of protein and starch. J. Sci. Food Agric. 1959, 10, 248-252. [CrossRef] 
41. Eliasson, A.C.; Larsson, K. Cereals in Breadmaking: A Molecular Colloidal Approach; CRC Press: Boca Raton, FL, USA, 1993; ISBN 9780824788162.

42. Kulkarni, R.G.; Ponte, J.G., Jr.; Kulp, K., Jr. Significance of gluten content as an index of flour quality. Cereal Chem. 1987, 64, 1-3.

43. Gaines, C.S. Collaborative study of methods for solvent retention capacity profiles (AACC Method 56-11). Cereal Food World 2000, 45, 303-306.

44. Mutwali, N.I.A.; Mustafa, A.I.; Gorafi, Y.S.A.; Ahmed, I.A.M. Effect of environment and genotypes on the physicochemical quality of the grains of newly developed wheat inbred lines. Food Sci. Nutr. 2016, 4, 508-520. [CrossRef] [PubMed]

45. Bonfil, D.J.; Posner, E.S. Can bread wheat quality be determined by gluten index? J. Cereal Sci. 2012, 56, 115-118. [CrossRef]

46. Kaur, A.; Singh, N.; Ahlawat, A.K.; Kaur, S.; Singh, A.M.; Chauhan, H.; Singh, G.P. Diversity in grain, flour, dough and gluten properties amongst Indian wheat cultivars varying in high molecular weight subunits (HMW-GS). Food Res. Int. 2013, 53, 63-72. [CrossRef]

47. Li, Y.; Wu, Y.; Hernandez-Espinosa, N.; Peña, R.J. The influence of drought and heat stress on the expression of end-use quality parameters of common wheat. J. Cereal Sci. 2013, 57, 73-78. [CrossRef]

48. Xiao, Z.S.; Park, S.H.; Chung, O.K.; Caley, M.S.; Seib, P.A. Solvent retention capacity values in relation to hard winter wheat and flour properties and straight-dough breadmaking quality. Cereal Chem. 2006, 83, 465-471. [CrossRef]

49. Rharrabti, Y.; Garcia del Moral, L.F.; Villegas, D.; Royo, C. Durum wheat quality in Mediterranean environments III. Stability and comparative methods in analyzing G $\times$ E interaction. Field Crop. Res. 2003, 80, 141-146. [CrossRef]

(C) 2018 by the authors. Licensee MDPI, Basel, Switzerland. This article is an open access article distributed under the terms and conditions of the Creative Commons Attribution (CC BY) license (http:/ / creativecommons.org/licenses/by/4.0/). 